\title{
Exploiting thermodynamic-kinetic synergetic effect for C3H6/C3H8 separation in pillar-layer MOFs
}

\author{
Yongwei Chen ${ }^{1}$, Houxiao $\mathrm{Wu}^{1}$, Liang $\mathrm{Yu}^{2}$, Shi $\mathrm{Tu}^{2}$, Ying $\mathrm{Wu}^{1}$, Zhong $\mathrm{Li}^{1}$, and Qibin $\mathrm{Xia}^{1}$ \\ ${ }^{1}$ South China University of Technology \\ ${ }^{2}$ South China University of Technology School of Chemistry and Chemical Engineering
}

June 26, 2021

\begin{abstract}
Efficient adsorption separation of propylene (C3H6) and propane (C3H8) can largely lower the energy consumption compared to the current energy-intensive cryogenic distillation. Herein, we report an isoreticular family of pillar-layer metal-organic frameworks (MOFs), M(AIP)(BPY)0.5 ( $\mathrm{M}=\mathrm{Co}, \mathrm{Ni}$, and $\mathrm{Zn}$ ), for efficient C3H6/C3H8 separation by exploiting thermodynamic and kinetic effects, circumventing disadvantages of each separation mechanism. The three MOFs feature an open metal site for each metal node and uniform but narrow one-dimensional (1D) channels, offering strong binding sites toward C3H6 via $\pi$ complexations while obstructing the diffusion of bulkier C3H8. The Ni-MOF shows the best separation performance based on the highest thermodynamic and kinetic $\mathrm{C} 3 \mathrm{H} 6 / \mathrm{C} 3 \mathrm{H} 8$ selectivity, further verified by computational simulations. Ni(AIP)(BPY)0.5 has a moderate $\mathrm{C} 3 \mathrm{H} 6$ uptake of $1.94 \mathrm{mmol} / \mathrm{g}$ but a remarkably high C3H6/C3H8 uptake ratio of 4.26 at $298 \mathrm{~K}$ and 1 bar. Efficient C3H6/C3H8 separation, good recyclability, moisture and water stability of Ni(AIP)(BPY)0.5 are confirmed.
\end{abstract}

\section{Exploiting thermodynamic-kinetic synergetic effect for $\mathrm{C}_{3} \mathrm{H}_{6} / \mathrm{C}_{3} \mathrm{H}_{8}$ separation in pillar-layer MOFs}

Yongwei Chen, ${ }^{1,2}$ Houxiao Wu, ${ }^{1}$ Liang Yu, ${ }^{1}$ Shi Tu, ${ }^{1}$ Ying Wu, ${ }^{* 1}$ Zhong Li,${ }^{1}$ and Qibin Xia,,${ }^{* 1,} 3$

${ }^{1}$ School of Chemistry and Chemical Engineering, South China University of Technology, Guangzhou 510640, China

${ }^{2}$ College of Chemical Engineering, Qingdao University of Science and Technology, Qingdao 266042, China

${ }^{3}$ South China Institute of Collaborative Innovation, Dongguan 523808, China

\begin{abstract}
Efficient adsorption separation of propylene $\left(\mathrm{C}_{3} \mathrm{H}_{6}\right)$ and propane $\left(\mathrm{C}_{3} \mathrm{H}_{8}\right)$ can largely lower the energy consumption compared to the current energy-intensive cryogenic distillation. Herein, we report an isoreticular family of pillar-layer metal-organic frameworks (MOFs), $\mathrm{M}(\mathrm{AIP})(\mathrm{BPY})_{0.5}(\mathrm{M}=\mathrm{Co}, \mathrm{Ni}$, and $\mathrm{Zn}$ ), for efficient $\mathrm{C}_{3} \mathrm{H}_{6} / \mathrm{C}_{3} \mathrm{H}_{8}$ separation by exploiting thermodynamic and kinetic effects, circumventing disadvantages of each separation mechanism. The three MOFs feature an open metal site for each metal node and uniform but narrow one-dimensional (1D) channels, offering strong binding sites toward $\mathrm{C}_{3} \mathrm{H}_{6}$ via $\pi$-complexations while obstructing the diffusion of bulkier $\mathrm{C}_{3} \mathrm{H}_{8}$. The Ni-MOF shows the best separation performance based on the highest thermodynamic and kinetic $\mathrm{C}_{3} \mathrm{H}_{6} / \mathrm{C}_{3} \mathrm{H}_{8}$ selectivity, further verified by computational simulations. $\mathrm{Ni}(\mathrm{AIP})(\mathrm{BPY})_{0.5}$ has a moderate $\mathrm{C}_{3} \mathrm{H}_{6}$ uptake of $1.94 \mathrm{mmol} / \mathrm{g}$ but a remarkably high $\mathrm{C}_{3} \mathrm{H}_{6} / \mathrm{C}_{3} \mathrm{H}_{8}$ uptake ratio of 4.26 at $298 \mathrm{~K}$ and 1 bar. Efficient $\mathrm{C}_{3} \mathrm{H}_{6} / \mathrm{C}_{3} \mathrm{H}_{8}$ separation, good recyclability, moisture and water stability of $\mathrm{Ni}(\mathrm{AIP})(\mathrm{BPY})_{0.5}$ are confirmed.
\end{abstract}

KEYWORDS: pillar- layer MOFs, adsorption, separation, $\mathrm{C}_{3} \mathrm{H}_{6}, \mathrm{C}_{3} \mathrm{H}_{8}$ 


\section{INTRODUCTION}

Propylene $\left(\mathrm{C}_{3} \mathrm{H}_{6}\right)$ is one of the most important building blocks in petrochemical industries that is widely used to produce polymers and high value-added organic chemicals. ${ }^{1-3}$ In 2016 , the worldwide production of $\mathrm{C}_{3} \mathrm{H}_{6}$ was up to 120 million tons, ${ }^{2}$ and its global demand has been expected to increase faster than that of ethylene $\left(\mathrm{C}_{2} \mathrm{H}_{4}\right)$ with an annual growth rate of $5 \% .{ }^{4} \mathrm{C}_{3} \mathrm{H}_{6}$ is typically produced by steam cracking of propane $\left(\mathrm{C}_{3} \mathrm{H}_{8}\right)$ or naphtha that generally coexists with its saturated counterpart $\mathrm{C}_{3} \mathrm{H}_{8} .{ }^{5}$ As a result, the separation of $\mathrm{C}_{3} \mathrm{H}_{6} / \mathrm{C}_{3} \mathrm{H}_{8}$ mixtures is an inevitable process to obtain polymer-grade ( $\left.>99.5 \%\right) \mathrm{C}_{3} \mathrm{H}_{6}$. Due to their close similarity in physical properties including the small difference in boiling points $\left(226 \mathrm{~K} \mathrm{for}_{3} \mathrm{H}_{6}\right.$ and $231 \mathrm{~K}$ for $\left.\mathrm{C}_{3} \mathrm{H}_{8}\right)$, close molecular sizes $\left(6.5 \times 4.0 \times 3.8 \AA^{3}\right.$ of $\mathrm{C}_{3} \mathrm{H}_{6}$ and $6.8 \times 4.2 \times 3.8 \AA^{3}$ of $\left.\mathrm{C}_{3} \mathrm{H}_{8}\right)$, and extremely close relative volatility (1.09-1.15), ${ }^{2,}{ }^{6} \mathrm{C}_{3} \mathrm{H}_{6} / \mathrm{C}_{3} \mathrm{H}_{8}$ separation is listed as one of the seven chemical separations to change the world. ${ }^{7}$ To date, industrial separation of $\mathrm{C}_{3} \mathrm{H}_{6}$ and $\mathrm{C}_{3} \mathrm{H}_{8}$ is commonly achieved by the established energy-intensive cryogenic distillation method that requires to be performed under very harsh operation conditions, including more than 180 theoretical trays, reflux ratio as high as 12-20, ultra-low operation temperature of $-30{ }^{\circ} \mathrm{C}$, and high operation pressure of $30 \mathrm{bar}^{2}{ }^{2}{ }^{8}, 9$ It has been reported that the theoretical energy consumption during $\mathrm{C}_{3} \mathrm{H}_{6} / \mathrm{C}_{3} \mathrm{H}_{8}$ separation process is estimated to be around 12.9 GJ per ton $\mathrm{C}_{3} \mathrm{H}_{6}$, obviously higher than that of $\mathrm{C}_{2} \mathrm{H}_{4} / \mathrm{C}_{2} \mathrm{H}_{6}$ separation which is theoretically calculated to be about 7.3 GJ per ton $\mathrm{C}_{2} \mathrm{H}_{4},{ }^{10}, 11$ leading to huge energy consumption. Consequently, it is highly demanded to develop energy-efficient methods for the separation of $\mathrm{C}_{3} \mathrm{H}_{6} / \mathrm{C}_{3} \mathrm{H}_{8}$ mixtures, and $\mathrm{C}_{3} \mathrm{H}_{6} / \mathrm{C}_{3} \mathrm{H}_{8}$ separation is viewed as one important industrial task to change the global energy footprint. ${ }^{12}$

Adsorption separation is an alternative technology to replace the traditional cryogenic distillation due to its energy-efficient feature and mild operation conditions. ${ }^{13}$ Moreover, adsorption separation has the potential capabilities of high separation selectivity, suitable for more difficult separation systems, such as ultralow concentration removal and azeotropes separation that can overcome the thermodynamic limitations, attracting tremendous attention for gas separation and purification applications. ${ }^{14}$ However, the development of $\mathrm{C}_{3} \mathrm{H}_{6} / \mathrm{C}_{3} \mathrm{H}_{8}$ separation through adsorption method is stagnant due to the poor separation performance of traditional porous materials, which is the key factor for achieving highly efficient adsorption-based $\mathrm{C}_{3} \mathrm{H}_{6} / \mathrm{C}_{3} \mathrm{H}_{8}$ separation. ${ }^{15}$

As an emerging class of porous crystalline materials, metal-organic frameworks (MOFs) assembled by inorganic metal nodes and organic linkers through coordination bonds have been widely studied in the field of gas separation and purification, ${ }^{16-21}$ including $\mathrm{C}_{3} \mathrm{H}_{6} / \mathrm{C}_{3} \mathrm{H}_{8}$ separation, ${ }^{1,22-24}$ due to their great structural diversity and easy tailorability. In terms of $\mathrm{C}_{3} \mathrm{H}_{6} / \mathrm{C}_{3} \mathrm{H}_{8}$ separation, the separation mechanisms in MOFs are classified into four categories: thermodynamic separation, kinetic separation, molecular sieve, and gateopening separation. ${ }^{25}$ With regard to kinetic separation, MOFs that separate $\mathrm{C}_{3} \mathrm{H}_{6} / \mathrm{C}_{3} \mathrm{H}_{8}$ by utilizing the difference in $\mathrm{C}_{3} \mathrm{H}_{6}$ and $\mathrm{C}_{3} \mathrm{H}_{8}$ diffusion rates are still underexplored and have the common drawback of low uptakes due to their restricted and narrow channels, such as BTO $(0.60 \mathrm{mmol} / \mathrm{g}),{ }^{26} \mathrm{DBTO}(1.40 \mathrm{mmol} / \mathrm{g}),{ }^{26}$ and ELM-12 (1.47 mmol/g). ${ }^{27}$ More importantly, most reports of kinetic $\mathrm{C}_{3} \mathrm{H}_{6} / \mathrm{C}_{3} \mathrm{H}_{8}$ separation merely focus on the kinetic selectivity based on pure $\mathrm{C}_{3} \mathrm{H}_{6}$ and $\mathrm{C}_{3} \mathrm{H}_{8}$ sorption kinetics profiles, and breakthrough tests $\mathrm{C}_{3} \mathrm{H}_{6} / \mathrm{C}_{3} \mathrm{H}_{8}$ mixtures were only performed on ELM- $12^{27}$ and Tb-ABTC ${ }^{28}$ so far. For the gate-opening separation, separating $\mathrm{C}_{3} \mathrm{H}_{6} / \mathrm{C}_{3} \mathrm{H}_{8}$ mixtures is realized by two flexible CPL- ${ }^{9}$ and NJU-Bai ${ }^{29}$ through the differences in $\mathrm{C}_{3} \mathrm{H}_{6}$ and $\mathrm{C}_{3} \mathrm{H}_{8}$ gate-opening pressures. However, the dynamic $\mathrm{C}_{3} \mathrm{H}_{6} / \mathrm{C}_{3} \mathrm{H}_{8}$ separation of CPL1 was required to be conducted at $273 \mathrm{~K}$ rather than room temperature, and additional energy is consumed to cool down the operation temperature. ${ }^{9}$ For NJU-Bai8, since the relatively low gate-opening pressures of $\mathrm{C}_{3} \mathrm{H}_{6}$ and $\mathrm{C}_{3} \mathrm{H}_{8}$ were 4.5 and $24.4 \mathrm{kPa}$ at $298 \mathrm{~K}$, He as the balance gas was necessary to control each partial pressure of $\mathrm{C}_{3} \mathrm{H}_{6}$ and $\mathrm{C}_{3} \mathrm{H}_{8}$ to be $20 \mathrm{kPa}$ that only $\mathrm{C}_{3} \mathrm{H}_{6}$ induced the gate-opening phenomenon during the breakthrough tests, making it unpractical for industrial application. ${ }^{29}$ Molecular sieving, as an ideal separation mechanism, is highly difficult to achieve by finely tune the MOF pore apertures that allow for the passing of smaller $\mathrm{C}_{3} \mathrm{H}_{6}$ molecules while excluding slightly bulkier $\mathrm{C}_{3} \mathrm{H}_{8}$. Indeed, the construction of MOFs with such subtle pores remains a great intractable task to discriminate the small difference in molecular sizes. Until now, NbOFFIVE-1-Ni, ${ }^{23} \mathrm{Y}$-abtc, ${ }^{24}$ and Co-gallate $\mathrm{MOF}^{1}$ have been exemplified in sieving separation of $\mathrm{C}_{3} \mathrm{H}_{6}$ and $\mathrm{C}_{3} \mathrm{H}_{8}$. Compared to the above three mechanisms, thermodynamic separation of $\mathrm{C}_{3} \mathrm{H}_{6} / \mathrm{C}_{3} \mathrm{H}_{8}$ has 
been the most widely explored as a feasible approach since the open metal sites (OMSs) within MOF frameworks can discriminately interact with $\mathrm{C}_{3} \mathrm{H}_{6}$ molecules via the formation of $\pi$-complexation interactions, such as MIL-100 ${ }^{30}$ and MOF-74 series. ${ }^{31}$ However, there usually exists the co-adsorption of the counterpart $\mathrm{C}_{3} \mathrm{H}_{8}$ and then hinders the high-purity $\mathrm{C}_{3} \mathrm{H}_{6}$ production, resulting in relatively moderate selectivity, such as the low $\mathrm{C}_{3} \mathrm{H}_{6}$ and $\mathrm{C}_{3} \mathrm{H}_{8}$ uptake ratio of MOF-74 series in the range of 1.12-1.31. ${ }^{2}$ In addition, these MOFs generally have limited stability when exposed to water and moisture, because these OMSs are also strong binding sites toward water molecules and then induce the breakdown of weak coordination bonds. ${ }^{32}$

Such disadvantageous effect on each separation mechanism may limit the utmost MOF separation performance of $\mathrm{C}_{3} \mathrm{H}_{6} / \mathrm{C}_{3} \mathrm{H}_{8}$ mixtures and means that there are still more efforts to further enhance the separation performance. On the other hand, the separation performance is simultaneously controlled by both thermodynamic and kinetic effects during a practical separation process. ${ }^{12}$ Hence, developing MOF adsorbents that can simultaneously exploit thermodynamic and kinetic mechanisms is appealing for $\mathrm{C}_{3} \mathrm{H}_{6} / \mathrm{C}_{3} \mathrm{H}_{8}$ separation whereas intractable to design and construct. Only a few unique MOFs have been demonstrated as suitable materials for both thermodynamic and kinetic separation mechanisms. ${ }^{8}{ }^{33}$ Despite these efforts, it remains scarce investigation for high-efficiency $\mathrm{C}_{3} \mathrm{H}_{6} / \mathrm{C}_{3} \mathrm{H}_{8}$ separation on MOFs. Inspired by the unique type structure of pillar-layer MOFs with an OMS for each metal node and uniform but narrow onedimensional (1D) channels, a series of pillar-layer MOFs, $\mathrm{M}(\mathrm{AIP})(\mathrm{BPY})_{0.5}(\mathrm{M}=\mathrm{Co}, \mathrm{Ni}$, and $\mathrm{Zn}$; AIP, 5-aminoisophthalic acid; BPY, 4,4'-bipyridine) to study the effect of transition metal ions $\left(\mathrm{Co}^{2+}, \mathrm{Ni}^{2+}\right.$, and $\mathrm{Zn}^{2+}$ ) on $\mathrm{C}_{3} \mathrm{H}_{6} / \mathrm{C}_{3} \mathrm{H}_{8}$ separation by exploiting thermodynamic-kinetic synergetic effect. Herein, we demonstrate that $\mathrm{Ni}(\mathrm{AIP})(\mathrm{BPY})_{0.5}$ has the best separation performance with the highest thermodynamic and kinetic selectivities of $\mathrm{C}_{3} \mathrm{H}_{6} / \mathrm{C}_{3} \mathrm{H}_{8}$ among the three MOFs.

\section{RESULTS AND DISCUSSION}

\subsection{Structural analysis and characterization.}

The solvothermal reaction of $\mathrm{M}\left(\mathrm{CH}_{3} \mathrm{COO}\right)_{2} \cdot 4 \mathrm{H}_{2} \mathrm{O}(\mathrm{M}=\mathrm{Co}$ and $\mathrm{Ni})$, AIP, and BPY in a mixed solution of water and methanol at 80 for 3 days yielded crystals of $\mathrm{M}(\mathrm{AIP})(\mathrm{BPY})_{0.5}(\mathrm{M}=\mathrm{Co}$ and $\mathrm{Ni})$. In contrast, $\mathrm{Zn}(\mathrm{AIP})(\mathrm{BPY})_{0.5}$ crystals were synthesized via the solvothermal reaction of $\mathrm{Zn}\left(\mathrm{NO}_{3}\right)_{2} * 6 \mathrm{H}_{2} \mathrm{O}$, AIP, and BPY in a mixed solution of water and $N, N$-dimethylformamide at 90 for 3 days. The three structures are isostructural and crystallized in the monoclinic space group of $P 2_{1} / c \cdot{ }^{34-37}$ In the structure of $\mathrm{M}(\mathrm{AIP})(\mathrm{BPY})_{0.5}$, each $\mathrm{M}$ in a distorted square pyramidal geometry is coordinated by three oxygen atoms from two AIP linkers (one monodentate mode and one bidentate mode from the carboxylate groups in two AIP linkers) and two nitrogen atoms (one in amino group in AIP and one from BPY), leaving an OMS for each metal node (Figure 1a). Structural analysis reveals that the coordination bonds between the metal node and AIP linker form a two-dimensional (2D) layer and then the adjacent layers are connected by BPY linker (Figure 1b), resulting in the three-dimensional (3D) network. In the pillar-layer framework, there exist 1D channels of dimension $8.8 \times 8.1,8.8 \times 7.9$, and $5.9 \times 8.1 \mathrm{~A}^{2}$ for $\mathrm{Co}, \mathrm{Ni}$, and Zn-based frameworks along the $y$-axis, respectively.
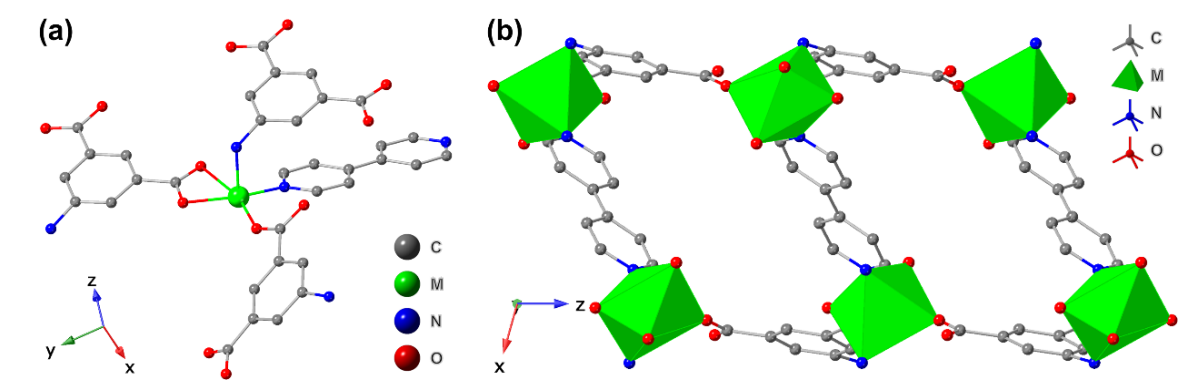

Figure 1. Crystal structures of $\mathrm{M}(\mathrm{AIP})(\mathrm{BPY})_{0.5}(\mathrm{M}=\mathrm{Co}, \mathrm{Ni}$, and $\mathrm{Zn})$ : (a) the coordination mode of metal node, (b) the $3 \mathrm{D}$ structure of $\mathrm{M}(\mathrm{AIP})(\mathrm{BPY})_{0.5}$ viewed along the $y$-axis. Color scheme: $\mathrm{M}(\mathrm{Co}, \mathrm{Ni}$, and $\mathrm{Zn})$ (green), C (gray), N (blue), O (red). H atoms are omitted for clarity. 
The bulk phase purities of the three $\mathrm{M}(\mathrm{AIP})(\mathrm{BPY})_{0.5}$ materials were verified by powder X-ray diffraction (PXRD) patterns (Figure S1), matching well the simulated data with the experimental PXRD patterns. Generally, the permanent porosity of porous materials is evaluated by $\mathrm{N}_{2}$ adsorption-desorption isotherms at $77 \mathrm{~K}$. However, no uptake of $\mathrm{N}_{2}$ at $77 \mathrm{~K}$ was observed for the three studied MOFs. Then $\mathrm{CO}_{2}$ was selected as the probe gas molecule and the isotherms at $195 \mathrm{~K}$ were measured (Figure 2). For Co(AIP)(BPY) 0.5 and $\mathrm{Ni}(\mathrm{AIP})(\mathrm{BPY})_{0.5}$, the type I isotherms of $\mathrm{CO}_{2}$ sorption were observed, indicating the microporous frameworks. The saturated $\mathrm{CO}_{2}$ uptakes reached 83 and $108 \mathrm{~cm}^{3} / \mathrm{g}$, respectively. However, the accessibility of $\mathrm{CO}_{2}$-induced gate-opening behavior at $\mathrm{P} / \mathrm{P}_{0}=0.506$ was observed for $\mathrm{Zn}(\mathrm{AIP})(\mathrm{BPY})_{0.5}$ and the maximum $\mathrm{CO}_{2}$ uptake reached $140 \mathrm{~cm}^{3} / \mathrm{g}$, in which the isotherm showed a type I characteristic with a steep uptake of $\mathrm{CO}_{2}$ in a relatively low pressure region and then an abrupt increase in $\mathrm{CO}_{2}$ uptake. It is probably due to the fact that the strength of $\mathrm{Zn}-\mathrm{N}$ bond is weaker than that of $\mathrm{Co}-\mathrm{N}$ and $\mathrm{Ni}-\mathrm{N}$, thereby resulting in more rotational flexibility of the pyridine ring in the BPY linker and then making it easier to trigger the structural transformation in $\mathrm{Zn}(\mathrm{AIP})(\mathrm{BPY})_{0.5}$. The calculated Brunauer-Emmett-Teller (BET) areas were 260,355 , and $244 \mathrm{~m}^{2} / \mathrm{g}$ for $\mathrm{Co}(\mathrm{AIP})(\mathrm{BPY})_{0.5}, \mathrm{Ni}(\mathrm{AIP})(\mathrm{BPY})_{0.5}$, and $\mathrm{Zn}(\mathrm{AIP})(\mathrm{BPY})_{0.5}$, respectively. Besides, thermogravimetric analysis (TGA) confirmed that the three MOFs were stable below $350{ }^{\circ} \mathrm{C}$ under air (Figure S2). Scanning electron microscopy (SEM) images revealed that the crystal morphologies of the three MOFs were relatively long lamellate particles (Figure S3).

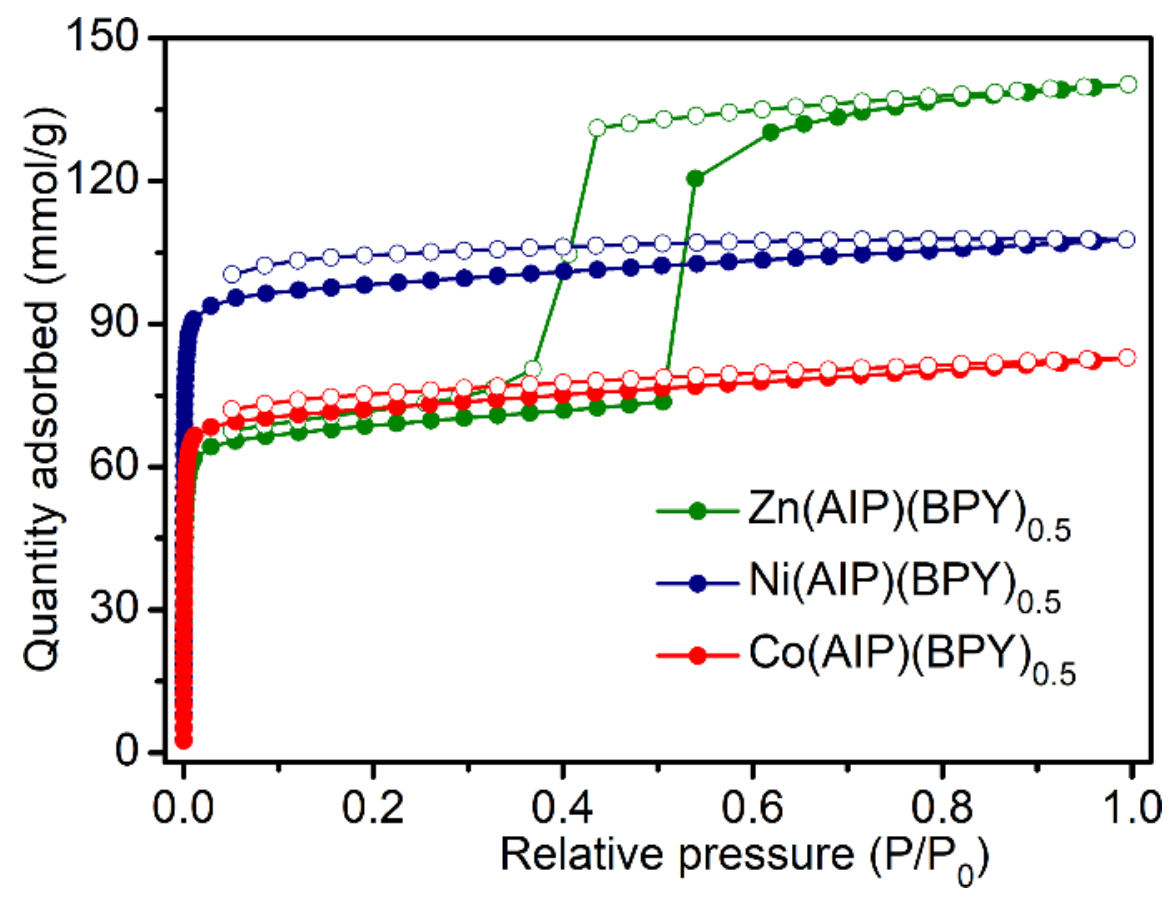

Figure 2. $\mathrm{CO}_{2}$ adsorption-desorption isotherms at $195 \mathrm{~K}$ of $\mathrm{M}(\mathrm{IPA})(\mathrm{BPY})_{0.5}(\mathrm{M}=\mathrm{Co}, \mathrm{Ni}$, and $\mathrm{Zn})$.

\subsection{Thermodynamic adsorption of propylene and propane.}

Due to the presence of OMS for each metal node in the pillar-layer structures, $\mathrm{C}_{3} \mathrm{H}_{6}$ can form strong $\pi$ complexation interactions with OMSs and thus the three MOFs have the feasibility of $\mathrm{C}_{3} \mathrm{H}_{6} / \mathrm{C}_{3} \mathrm{H}_{8}$ separation. Motivated by this point, single-component sorption isotherms of $\mathrm{C}_{3} \mathrm{H}_{6}$ and $\mathrm{C}_{3} \mathrm{H}_{8}$ at three temperatures (288, 298 , and $308 \mathrm{~K}$ ) were measured to test their $\mathrm{C}_{3} \mathrm{H}_{6} / \mathrm{C}_{3} \mathrm{H}_{8}$ separation performances. As demonstrated in Figure $3 \mathrm{a}-3 \mathrm{c}$, the $\mathrm{C}_{3} \mathrm{H}_{6}$ sorption isotherms of the three MOFs showed a type I feature that steep sorption curves were observed in the relatively low pressure region, meaning strong adsorption interactions between $\mathrm{C}_{3} \mathrm{H}_{6}$ and the three frameworks, due to the existence of $\pi$-complexation interactions toward $\mathrm{C}_{3} \mathrm{H}_{6}$ in these microporous materials. Particularly, no gate-opening behavior of $\mathrm{C}_{3} \mathrm{H}_{6}$ sorption was observed in $\mathrm{Zn}(\mathrm{AIP})(\mathrm{BPY})_{0.5}$, excluding 
the gate-opening separation mechanism. At $298 \mathrm{~K}$ and 1 bar, the saturated uptakes of $\mathrm{C}_{3} \mathrm{H}_{6}$ were 1.99, 1.94, and $1.87 \mathrm{mmol} / \mathrm{g}$ for $\mathrm{Co}(\mathrm{AIP})(\mathrm{BPY})_{0.5}, \mathrm{Ni}(\mathrm{AIP})(\mathrm{BPY})_{0.5}$, and $\mathrm{Zn}(\mathrm{AIP})(\mathrm{BPY})_{0.5}$, respectively. As the temperature increased $(308 \mathrm{~K})$ or decreased $(288 \mathrm{~K})$, similar trends of the $\mathrm{C}_{3} \mathrm{H}_{6}$ sorption isotherms were retained. In contrast, the $\mathrm{C}_{3} \mathrm{H}_{8}$ sorption isotherms were nearly linear, in which the $\mathrm{C}_{3} \mathrm{H}_{8}$ uptakes monotonously increased with the increase of pressure under these measured conditions, due to the relatively weak $\mathrm{MOF}-\mathrm{C}_{3} \mathrm{H}_{8}$ interactions. The $\mathrm{C}_{3} \mathrm{H}_{8}$ uptakes were remarkably lower than those of $\mathrm{C}_{3} \mathrm{H}_{6}$ for each MOF at the same measured temperature. Although the $\mathrm{C}_{3} \mathrm{H}_{6}$ uptakes of the three MOFs were closely similar, the differences in the $\mathrm{C}_{3} \mathrm{H}_{8}$ uptakes at the same temperature were more obvious. The Ni-based MOF had the smallest $\mathrm{C}_{3} \mathrm{H}_{6}$ uptakes among them. At $298 \mathrm{~K}$ and 1 bar, the $\mathrm{C}_{3} \mathrm{H}_{8}$ uptakes of $\mathrm{Co}(\mathrm{AIP})(\mathrm{BPY})_{0.5}, \mathrm{Ni}(\mathrm{AIP})(\mathrm{BPY})_{0.5}$, and $\mathrm{Zn}(\mathrm{AIP})(\mathrm{BPY})_{0.5}$ were $0.49,0.45$, and $0.59 \mathrm{mmol} / \mathrm{g}$, respectively. The obvious differences in $\mathrm{C}_{3} \mathrm{H}_{6}$ and $\mathrm{C}_{3} \mathrm{H}_{8}$ uptakes preliminarily verified the feasibility of the three MOFs for $\mathrm{C}_{3} \mathrm{H}_{6} / \mathrm{C}_{3} \mathrm{H}_{8}$ separation.
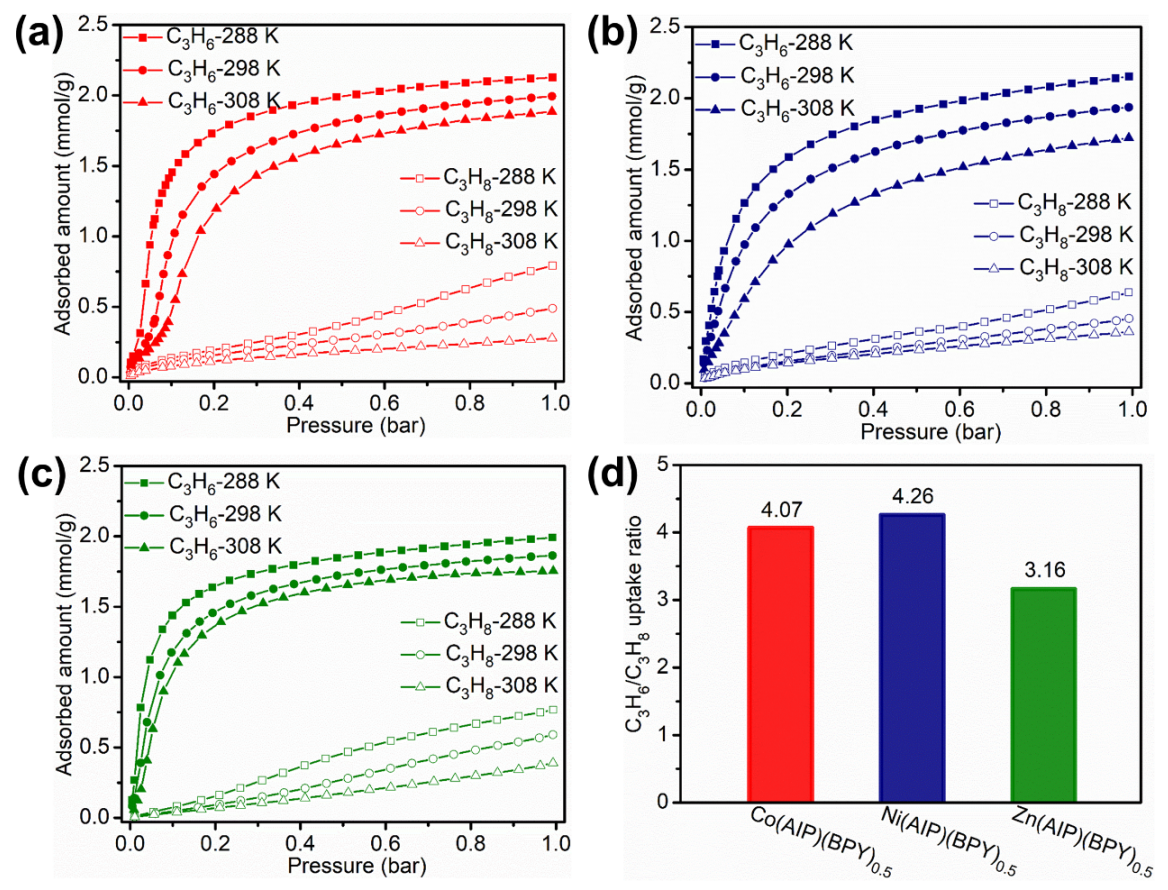

Figure 3. $\mathrm{C}_{3} \mathrm{H}_{6}$ and $\mathrm{C}_{3} \mathrm{H}_{8}$ sorption isotherms of (a) $\mathrm{Co}(\mathrm{AIP})(\mathrm{BPY})_{0.5}$, (b) $\mathrm{Ni}(\mathrm{AIP})(\mathrm{BPY})_{0.5}$, and (c) $\mathrm{Zn}(\mathrm{AIP})(\mathrm{BPY})_{0.5}$. (d) Ratio of $\mathrm{C}_{3} \mathrm{H}_{6}$ and $\mathrm{C}_{3} \mathrm{H}_{8}$ uptakes at $298 \mathrm{~K}$ and 1 bar.

To evaluate the $\mathrm{C}_{3} \mathrm{H}_{6} / \mathrm{C}_{3} \mathrm{H}_{8}$ separation performance of the three MOFs, the $\mathrm{C}_{3} \mathrm{H}_{6} / \mathrm{C}_{3} \mathrm{H}_{8}$ uptake ratio at $298 \mathrm{~K}$ was calculated (Figure 3d), an important significant index for separation selectivity. The values of the record-high $\mathrm{C}_{3} \mathrm{H}_{6} / \mathrm{C}_{3} \mathrm{H}_{8}$ uptake ratios of $\mathrm{Co}(\mathrm{AIP})(\mathrm{BPY})_{0.5}, \mathrm{Ni}(\mathrm{AIP})(\mathrm{BPY})_{0.5}$, and $\mathrm{Zn}(\mathrm{AIP})(\mathrm{BPY})_{0.5}$ were $4.07,4.26$ and 3.16, respectively. These values are highly higher than those of the MOFs based on the thermodynamic effect for $\mathrm{C}_{3} \mathrm{H}_{6} / \mathrm{C}_{3} \mathrm{H}_{8}$ separation, such as $\mathrm{Cu}(0.6) @ M I L-100(\mathrm{Fe})$ (1.34) ${ }^{38} \mathrm{Cu}$-BTC (1.12), ${ }^{39} \mathrm{Mn}_{2}$ (m-dobdc) (1.25), ${ }^{22} \mathrm{Mg}$-MOF-74 (1.33), ${ }^{40} \mathrm{Mn}_{2}$ (dobdc) (1.31), ${ }^{31} \mathrm{MAF}-23-\mathrm{O}$ (1.17), ${ }^{8}$ SIFSIX-2-Cu-I (1.59), ${ }^{2} \mathrm{ZnAtzPO}_{4}$ (1.79), ${ }^{33}$ but much lower than those of molecular sieving separation of $\mathrm{C}_{3} \mathrm{H}_{6} / \mathrm{C}_{3} \mathrm{H}_{8}$ including Co-gallate, ${ }^{1}$ NbOFFIVE-1-Ni, ${ }^{23}$ Y-abtc. ${ }^{24}$ The results confirmed that the three MOFs would be new benchmark MOF adsorbents for $\mathrm{C}_{3} \mathrm{H}_{6} / \mathrm{C}_{3} \mathrm{H}_{8}$ separation via thermodynamic effect.

Then the adsorbed solution theory (IAST) was used to assess the separation selectivity of the $\mathrm{C}_{3} \mathrm{H}_{6} / \mathrm{C}_{3} \mathrm{H}_{8}(50: 50, \mathrm{v} / \mathrm{v})$ mixture. ${ }^{41}$ Although $\mathrm{Co}(\mathrm{AIP})(\mathrm{BPY})_{0.5}$ and $\mathrm{Zn}(\mathrm{AIP})(\mathrm{BPY})_{0.5}$ both had remarkably high $\mathrm{C}_{3} \mathrm{H}_{6} / \mathrm{C}_{3} \mathrm{H}_{8}$ selectivities of 21 and 20 at 1 bar, Ni(AIP)(BPY) ${ }_{0.5}$ showed the highest IAST-predicted selectivity of $\mathrm{C}_{3} \mathrm{H}_{6} / \mathrm{C}_{3} \mathrm{H}_{8}$ at $298 \mathrm{~K}$ among the three MOFs in Figure 4a. It means that the $\mathrm{Ni}$ mode in the pillar-layer structure has the best separation performance among a series of transition metals (Co, Ni, 
and $\mathrm{Zn})$. The selectivity was calculated to be 31 at 1 bar, which is remarkably higher than most reported MOFs under similar conditions, such as $\mathrm{Fe}_{2}$ (dobdc) (15), ${ }^{42} \mathrm{Cr}_{3}(\mathrm{btc})_{2}(3),{ }^{42} \mathrm{Cu}_{3}(\mathrm{btc}){ }_{2}(6),{ }^{42} \mathrm{MAF}-23$ (3), ${ }^{8}$ and MAF-23-O (9), ${ }^{8}$ meaning the potential for efficient $\mathrm{C}_{3} \mathrm{H}_{6} / \mathrm{C}_{3} \mathrm{H}_{8}$ separation.

Moving forward, the isosteric heat of adsorption $\left(\mathrm{Q}_{\mathrm{st}}\right)$, a key thermodynamic parameter, was calculated to evaluate the interactions between $\mathrm{C}_{3} \mathrm{H}_{6}$ molecules and the three MOF frameworks by using the Virial equation and the isotherms at the three temperatures (Figures 3a-3c, S4-S6, and Table S1). The $\mathrm{Q}_{\mathrm{st}}$ values of $\mathrm{Ni}(\mathrm{AIP})(\mathrm{BPY})_{0.5}(48.70-49.75 \mathrm{~kJ} / \mathrm{mol})$ and $\mathrm{Co}(\mathrm{AIP})(\mathrm{BPY})_{0.5}(41.79-40.22 \mathrm{~kJ} / \mathrm{mol})$ slightly decreases as the adsorbed uptake increased while the $\mathrm{Q}_{\text {st }}$ values of $\mathrm{Zn}(\mathrm{AIP})(\mathrm{BPY})_{0.5}$ remained almost constant (40.67$40.64 \mathrm{~kJ} / \mathrm{mol})$, indicating that the pore surfaces of $\mathrm{Zn}(\mathrm{AIP})(\mathrm{BPY})_{0.5}$ are more homogeneous than those of $\mathrm{Ni}(\mathrm{AIP})(\mathrm{BPY})_{0.5}$ and $\mathrm{Co}(\mathrm{AIP})(\mathrm{BPY})_{0.5} \cdot{ }^{43}$ It is observed that the $\mathrm{Q}_{\mathrm{st}}$ values of $\mathrm{Ni}(\mathrm{AIP})(\mathrm{BPY})_{0.5}$ are much higher than those of Co-MOF and $\mathrm{Zn}-\mathrm{MOF}$, meaning that the interactions of $\mathrm{C}_{3} \mathrm{H}_{6}$ toward the Ni-based framework are much stronger than those of Co- and $\mathrm{Zn}$-based frameworks. Furthermore, the interactions between $\mathrm{C}_{3} \mathrm{H}_{6}$ and the Co-MOF or Zn-MOF are closely similar due to the close $\mathrm{Q}_{\mathrm{st}}$ values under each $\mathrm{C}_{3} \mathrm{H}_{6}$ loading. Compared to the $\mathrm{Zn}-\mathrm{MOF}$, the Co-MOF had higher $\mathrm{Q}_{\mathrm{st}}$ values at the initial $\mathrm{C}_{3} \mathrm{H}_{6}$ loading due to the larger steric hindrance in the narrow channels within the pillar-layer framework. The related reasons will be further discussed in the following section. From the perspective of thermodynamic effect, it further confirms that the Ni-MOF shows the best $\mathrm{C}_{3} \mathrm{H}_{6} / \mathrm{C}_{3} \mathrm{H}_{8}$ separation performance among the three MOFs.
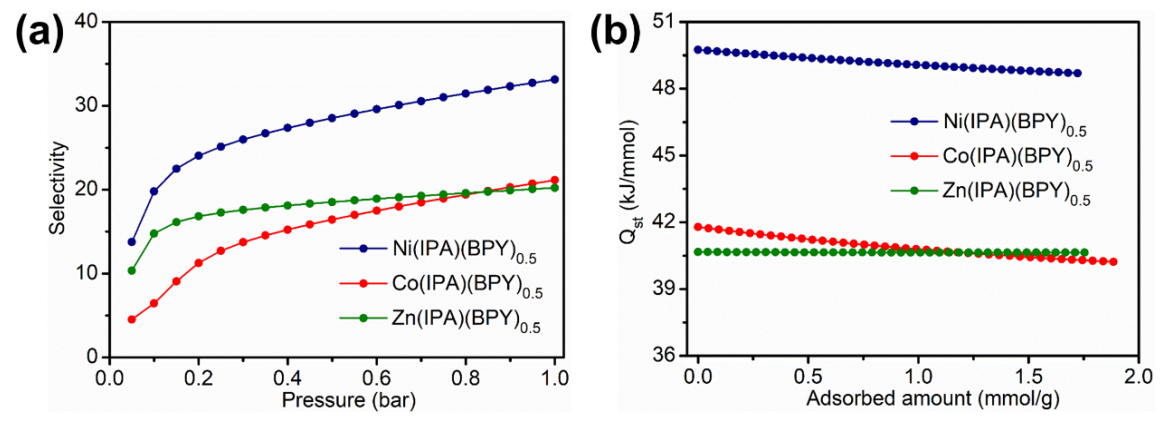

Figure 4. (a) IAST-predicted selectivities of $\mathrm{C}_{3} \mathrm{H}_{6} / \mathrm{C}_{3} \mathrm{H}_{8}(50: 50, \mathrm{v} / \mathrm{v})$ at $298 \mathrm{~K}$ for $\mathrm{M}(\mathrm{IPA})(\mathrm{BPY})_{0.5}(\mathrm{M}=$ $\mathrm{Co}, \mathrm{Ni}$, and $\mathrm{Zn})$. (b) Isosteric heats of isotherms of $\mathrm{C}_{3} \mathrm{H}_{6}$ on $\mathrm{M}(\mathrm{IPA})(\mathrm{BPY})_{0.5}(\mathrm{M}=\mathrm{Co}, \mathrm{Ni}$, and $\mathrm{Zn})$.

\subsection{Kinetic adsorption of propylene and propane.}

For the industrial applications, kinetic adsorption tests were also performed by measuring the time-dependent adsorbed amount profiles of $\mathrm{C}_{3} \mathrm{H}_{6}$ and $\mathrm{C}_{3} \mathrm{H}_{8}$ at $303 \mathrm{~K}$ and 0.5 bar to provide more insights into the sorption behaviors of the three MOFs (Figure S7-S9). As shown in Figure S7, the $\mathrm{C}_{3} \mathrm{H}_{6}$ and $\mathrm{C}_{3} \mathrm{H}_{8}$ uptakes of $\mathrm{Co}(\mathrm{AIP})(\mathrm{BPY})_{0.5}$ reached equilibrium within about 36 and $81 \mathrm{~min}$ at $303 \mathrm{~K}$, respectively. For the kinetic sorption of $\mathrm{Ni}(\mathrm{AIP})(\mathrm{BPY})_{0.5}$ in Figure $\mathrm{S} 8$, the kinetic uptake of $\mathrm{C}_{3} \mathrm{H}_{6}$ was highly faster than that of $\mathrm{C}_{3} \mathrm{H}_{8}$. The initial $\mathrm{C}_{3} \mathrm{H}_{6}$ uptake increased steeply within $1 \mathrm{~min}$ and reached $1.21 \mathrm{mmol} / \mathrm{g}$ at $1 \mathrm{~min}$. Then continuous increase in $\mathrm{C}_{3} \mathrm{H}_{6}$ uptake was observed until $100 \mathrm{~min}$. In contrast, it was observed a nearly linear increase in the uptake of $\mathrm{C}_{3} \mathrm{H}_{8}$ as the function of time, indicating its slow diffusion. However, the respective equilibrium times of $\mathrm{C}_{3} \mathrm{H}_{6}$ and $\mathrm{C}_{3} \mathrm{H}_{8}$ for $\mathrm{Zn}(\mathrm{AIP})(\mathrm{BPY})_{0.5}$ were about merely 1 and $4 \mathrm{~min}$, demonstrating the corresponding fastest diffusion rates of $\mathrm{C}_{3} \mathrm{H}_{6}$ and $\mathrm{C}_{3} \mathrm{H}_{8}$ in the three pillar-layer structures. Then the micropore diffusion model was selected to fit the dynamic adsorption profiles (Figure 5). The diffusion time constants (D') of $\mathrm{C}_{3} \mathrm{H}_{6}$ were calculated to be $0.0036,0.1012$, and 0.4934 at $303 \mathrm{~K}$ for $\mathrm{Co}(\mathrm{AIP})(\mathrm{BPY})_{0.5}, \mathrm{Ni}(\mathrm{AIP})(\mathrm{BPY})_{0.5}$, and $\mathrm{Zn}(\mathrm{AIP})(\mathrm{BPY})_{0.5}$, respectively, following the order of $\mathrm{Co}-\mathrm{MOF}<\mathrm{Ni}-\mathrm{MOF}<\mathrm{Zn}-\mathrm{MOF}$ toward $\mathrm{C}_{3} \mathrm{H}_{6}$ diffusion in the pillar-layer frameworks. Meantime, the corresponding values of $\mathrm{C}_{3} \mathrm{H}_{8}$ were $0.0005,0.0011$, and 0.0348 for the three MOF frameworks, obviously lower than that of respective $\mathrm{C}_{3} \mathrm{H}_{6}$, due to the bulkier $\mathrm{C}_{3} \mathrm{H}_{8}$ molecule resulting in larger steric hindrance and consequently leading to lower diffusion rate within the micropores. As a result, the kinetic selectivities of $\mathrm{Co}(\mathrm{AIP})(\mathrm{BPY})_{0.5}, \mathrm{Ni}(\mathrm{AIP})(\mathrm{BPY})_{0.5}$, and $\mathrm{Zn}(\mathrm{AIP})(\mathrm{BPY})_{0.5}$ were determined to be 7.2, 92.0, and 14.2, respectively. From the perspective of kinetic effect, it also verifies 
that the Ni-MOF has the best $\mathrm{C}_{3} \mathrm{H}_{6} / \mathrm{C}_{3} \mathrm{H}_{8}$ separation performance among the three MOFs, which Ni-MOF can shorten the industrial operating time and enhance the whole productivity of $\mathrm{C}_{3} \mathrm{H}_{6} / \mathrm{C}_{3} \mathrm{H}_{8}$ separation.
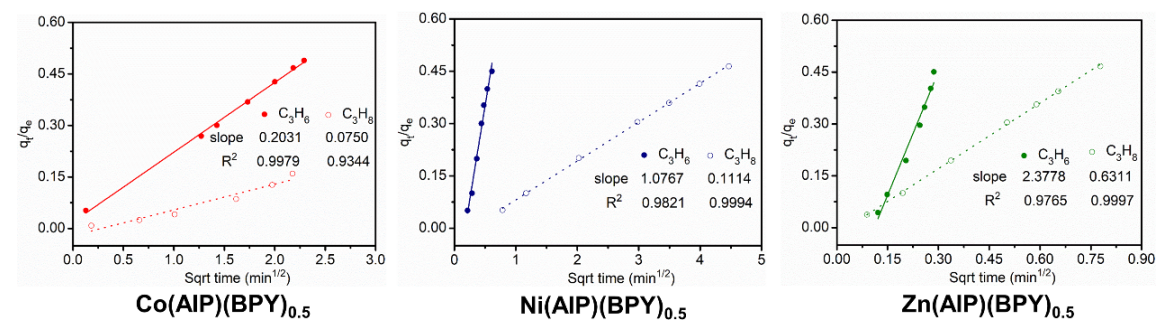

Figure 5. Linear fittings of $\mathrm{C}_{3} \mathrm{H}_{6}$ (solid) and $\mathrm{C}_{3} \mathrm{H}_{8}$ (open) on $\mathrm{M}(\mathrm{AIP})(\mathrm{BPY})_{0.5}(\mathrm{M}=\mathrm{Co}, \mathrm{Ni}$, and $\mathrm{Zn}$ ) for the calculation of diffusional time constant at $303 \mathrm{~K}$.

\subsection{Molecular simulations of gas adsorption mechanism.}

To reveal the adsorption mechanism in the three pillar-layer structures, molecular simulations were performed to investigate the preferential binding sites of $\mathrm{C}_{3} \mathrm{H}_{6}$ in the frameworks. The calculated results in Figure 6 demonstrated that $\mathrm{C}_{3} \mathrm{H}_{6}$ molecules were mainly concentrated in the center of the $1 \mathrm{D}$ channels in Co- and Zn-based pillar-layer frameworks, whereas Ni-based counterpart exhibited a more dense and bulky binding space for $\mathrm{C}_{3} \mathrm{H}_{6}$ molecules in the channels. In addition, the interaction energy distributions of a single $\mathrm{C}_{3} \mathrm{H}_{6}$ molecule in the three MOFs were calculated in Figure S10, in which the interaction energy distributions were located in the ranges of $-16.55-9.15,-16.55-9.45$, and $-15.75-8.55 \mathrm{kcal} / \mathrm{mol}$ for $\mathrm{Co}(\mathrm{AIP})(\mathrm{BPY})_{0.5}$, $\mathrm{Ni}(\mathrm{AIP})(\mathrm{BPY})_{0.5}$, and $\mathrm{Zn}(\mathrm{AIP})(\mathrm{BPY})_{0.5}$, respectively. Although the interaction energy distributions in the Co-MOF are close to those in Ni-MOF, the peak width of $\mathrm{C}_{3} \mathrm{H}_{6}$ could be another way to reveal the interaction affinity between $\mathrm{C}_{3} \mathrm{H}_{6}$ and the framework. The peak width follows the order: $\mathrm{Ni}(\mathrm{AIP})(\mathrm{BPY})_{0.5}(2.04$ $\mathrm{kcal} / \mathrm{mol})>\mathrm{Zn}(\mathrm{AIP})(\mathrm{BPY})_{0.5}(1.90 \mathrm{kcal} / \mathrm{mol})>\mathrm{Co}(\mathrm{AIP})(\mathrm{BPY})_{0.5}(1.45 \mathrm{kcal} / \mathrm{mol})$, well consistent with the results of $\mathrm{C}_{3} \mathrm{H}_{6}$ adsorption density distributions in Figure 6, further verifying that the Ni nodes are more preferential for adsorbing $\mathrm{C}_{3} \mathrm{H}_{6}$ compared to the corresponding $\mathrm{Co}$ and $\mathrm{Zn}$ nodes in the targeted structures. Moreover, the adsorption configuration of $\mathrm{C}_{3} \mathrm{H}_{6}$ also demonstrated a relatively closer interaction distance from the wall of pores in $\mathrm{Ni}(\mathrm{AIP})(\mathrm{BPY})_{0.5}$ and $\mathrm{Zn}(\mathrm{AIP})(\mathrm{BPY})_{0.5}$ compared to that of $\mathrm{Co}(\mathrm{AIP})(\mathrm{BPY})_{0.5}$. These observations explained why the $\mathrm{C}_{3} \mathrm{H}_{6}$ uptake and $\mathrm{C}_{3} \mathrm{H}_{6} / \mathrm{C}_{3} \mathrm{H}_{8}$ selectivity of the Co-MOF in the low pressure region are relatively lower than those of the corresponding $\mathrm{Ni}-$ and $\mathrm{Zn}-\mathrm{MOF}$ in Figure $3 \mathrm{a}$ and $4 \mathrm{a}$ under the same conditions.
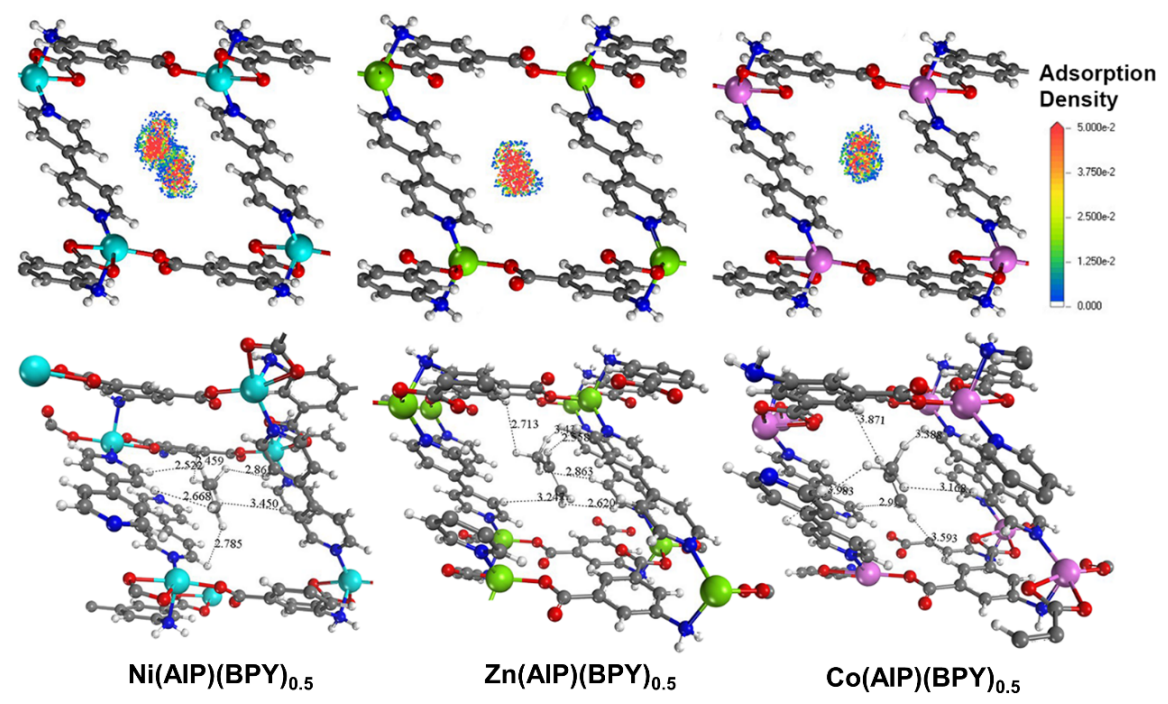
Figure 6. Adsorption density distribution at $298 \mathrm{~K}$ and 1 bar, and the adsorption configuration of $\mathrm{C}_{3} \mathrm{H}_{6}$ in $\mathrm{M}(\mathrm{AIP})(\mathrm{BPY})_{0.5}(\mathrm{M}=\mathrm{Co}, \mathrm{Ni}$, and $\mathrm{Zn})$.

Apart from the thermodynamic differences in the three MOFs, the diffusion behaviors of $\mathrm{C}_{3} \mathrm{H}_{6}$ in the pores were also examined by using molecular dynamic simulations to investigate the kinetic characteristics. As shown in Figure 7, we simulated a 20 ns diffusion process of $\mathrm{C}_{3} \mathrm{H}_{6}$ passing through the $1 \mathrm{D}$ channels in the three MOFs. In the case of $\mathrm{Zn}(\mathrm{AIP})(\mathrm{BPY})_{0.5}$, the $\mathrm{C}_{3} \mathrm{H}_{6}$ molecule migrated forward about $6.73 \AA$ in the first $10 \mathrm{~ns}$ and $7.95 \AA$ in the second $10 \mathrm{~ns}$, which is faster than that in the case of $\mathrm{Ni}(\mathrm{AIP})(\mathrm{BPY})_{0.5}$. It is interesting that in the case of $\mathrm{Co}(\mathrm{AIP})(\mathrm{BPY})_{0.5}$, the $\mathrm{C}_{3} \mathrm{H}_{6}$ molecule migrated backward in the second 10 ns, indicating that the diffusion of $\mathrm{C}_{3} \mathrm{H}_{6}$ has been hindered in the $1 \mathrm{D}$ narrow channels of $\mathrm{Co}(\mathrm{AIP})(\mathrm{BPY})_{0.5}$. These calculated results are consistent with our experiments in Figure 5.
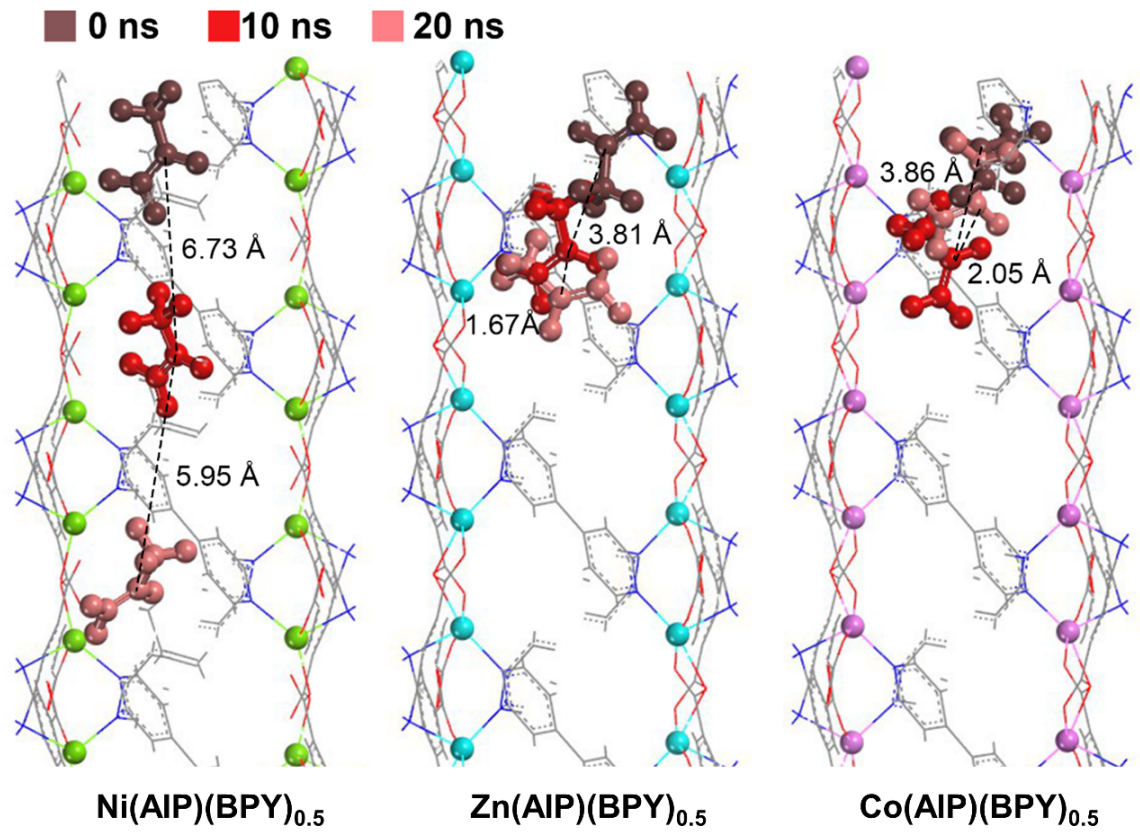

Figure 7. Molecular dynamic (MD) simulation of $\mathrm{C}_{3} \mathrm{H}_{6}$ passing through the $1 \mathrm{D}$ channels of $\mathrm{M}(\mathrm{AIP})(\mathrm{BPY})_{0.5}$ $(\mathrm{M}=\mathrm{Co}, \mathrm{Ni}$, and $\mathrm{Zn})$. The metal atoms color code: $\mathrm{Zn}$ (green), $\mathrm{Ni}$ (cyan), Co (pink). The $\mathrm{C}_{3} \mathrm{H}_{6}$ molecule colored by brown, red and salmon indicated a snapshot of MD simulation in 0, 10, and $20 \mathrm{~ns}$, respectively.

\subsection{Breakthrough Experiments and Cycling Tests.}

Motivated by the corresponding highest thermodynamic and kinetic selectivities of $\mathrm{C}_{3} \mathrm{H}_{6} / \mathrm{C}_{3} \mathrm{H}_{8}$ mixture among the three MOFs, breakthrough experiments of the pillar-layer Ni-based MOF with uniform but narrow pore structure were performed to assess the actual separation performance of $\mathrm{C}_{3} \mathrm{H}_{6} / \mathrm{C}_{3} \mathrm{H}_{8}$ under ambient conditions. From the breakthrough curves illustrated in Figure 8a, the results indicated that $\mathrm{Ni}(\mathrm{AIP})(\mathrm{BPY})_{0.5}$ could be a highly promising absorbent for efficient $\mathrm{C}_{3} \mathrm{H}_{6} / \mathrm{C}_{3} \mathrm{H}_{8}$ separation. Obviously, $\mathrm{C}_{3} \mathrm{H}_{8}$ component was quickly eluted through the packed column after 3.4 min whereas $\mathrm{C}_{3} \mathrm{H}_{6}$ was trapped in the adsorption bed until nearly $8.5 \mathrm{~min}$. The retention time of $\mathrm{C}_{3} \mathrm{H}_{6}$ is 2.5 times more than that of $\mathrm{C}_{3} \mathrm{H}_{8}$. The obvious breakthrough time interval between $\mathrm{C}_{3} \mathrm{H}_{6}$ and $\mathrm{C}_{3} \mathrm{H}_{8}$ means that $\mathrm{Ni}(\mathrm{AIP})(\mathrm{BPY})_{0.5}$ is highly effective for $\mathrm{C}_{3} \mathrm{H}_{6} / \mathrm{C}_{3} \mathrm{H}_{8}$ separation. The high practical $\mathrm{C}_{3} \mathrm{H}_{6} / \mathrm{C}_{3} \mathrm{H}_{8}$ selectivity of $\mathrm{Ni}(\mathrm{AIP})(\mathrm{BPY})_{0.5}$ should be contributed by the thermodynamic-kinetic synergetic effect. Furthermore, the elution of $\mathrm{C}_{3} \mathrm{H}_{6}$ was accompanied by an obvious roll-up phenomenon of $\mathrm{C}_{3} \mathrm{H}_{8}$ with a $\mathrm{C} / \mathrm{C}_{0}$ value up to 1.4 , suggesting that the already adsorbed $\mathrm{C}_{3} \mathrm{H}_{8}$ molecules were largely displaced by $\mathrm{C}_{3} \mathrm{H}_{6}$, indicative of the stronger competition adsorption of $\mathrm{C}_{3} \mathrm{H}_{6}$ over $\mathrm{C}_{3} \mathrm{H}_{8}$ on the OMSs of $\mathrm{Ni}(\mathrm{AIP})(\mathrm{BPY})_{0.5}$. In addition, cycling breakthrough experiments were performed to check the recycle ability. During 5 consecutive cycles, there were no obvious 
differences in the breakthrough time and time interval for $\mathrm{C}_{3} \mathrm{H}_{6} / \mathrm{C}_{3} \mathrm{H}_{8}$ mixtures, confirming good recycle ability of $\mathrm{Ni}(\mathrm{AIP})(\mathrm{BPY})_{0.5}$ and favorable feature for industrial applications.
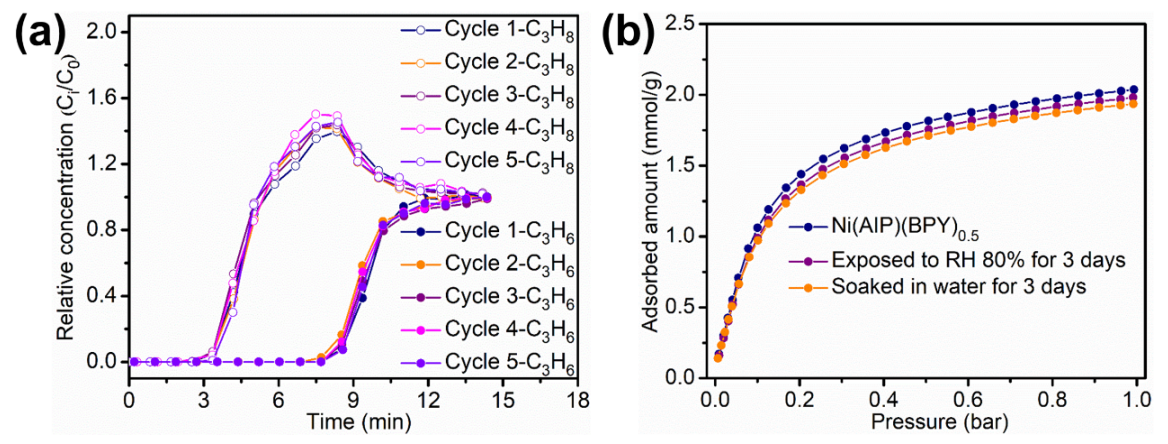

Figure 8. (a) Breakthrough curves of $\mathrm{C}_{3} \mathrm{H}_{6} / \mathrm{C}_{3} \mathrm{H}_{8}(50 / 50, \mathrm{v} / \mathrm{v})$ mixture on $\mathrm{Ni}(\mathrm{AIP})(\mathrm{BPY})_{0.5}$ at $298 \mathrm{~K}$ and 1 bar for five cycles. (b) $\mathrm{C}_{3} \mathrm{H}_{6}$ sorption isotherms at $298 \mathrm{~K}$ of $\mathrm{Ni}(\mathrm{AIP})(\mathrm{BPY})_{0.5}$ after moisture and water tests.

\subsection{Moisture and Water Stability Tests.}

Since material stability is another important factor to be considered in practical applications, moisture and water tests were carried out after being exposed to humid conditions $(\mathrm{RH} 80 \%)$ and soaked in water for 3 days, respectively. The PXRD patterns in Figure S11 showed no obvious difference in the crystallinity of the robust $\mathrm{Ni}(\mathrm{AIP})(\mathrm{BPY})_{0.5}$ framework, confirming that the structure remained intact and no phase transition occurred. Moreover, the $\mathrm{C}_{3} \mathrm{H}_{6}$ sorption isotherms revealed that the $\mathrm{C}_{3} \mathrm{H}_{6}$ uptakes of the moisture-exposed and water-soaked $\mathrm{Ni}(\mathrm{AIP})(\mathrm{BPY})_{0.5}$ remained almost no decreased (Figure 8b). These results allow for $\mathrm{Ni}(\mathrm{AIP})(\mathrm{BPY})_{0.5}$ as a promising adsorbent for industrial separation of $\mathrm{C}_{3} \mathrm{H}_{6} / \mathrm{C}_{3} \mathrm{H}_{8}$ separation.

\section{CONCLUSIONS}

In summary, we have reported a series of pillar-layer MOFs constructed by different transition metals (Co, $\mathrm{Ni}$, and $\mathrm{Zn}$ ) for $\mathrm{C}_{3} \mathrm{H}_{6} / \mathrm{C}_{3} \mathrm{H}_{8}$ separation. For the three MOFs, thermodynamic and kinetic results confirm that $\mathrm{Ni}(\mathrm{AIP})(\mathrm{BPY})_{0.5}$ has the best of $\mathrm{C}_{3} \mathrm{H}_{6} / \mathrm{C}_{3} \mathrm{H}_{8}$ separation performance. The origin of the thermodynamickinetic synergetic effect on $\mathrm{C}_{3} \mathrm{H}_{6} / \mathrm{C}_{3} \mathrm{H}_{8}$ separation simultaneously comes from the OMSs on the metal node and optimal pore structure, enabling strong adsorption interactions toward $\mathrm{C}_{3} \mathrm{H}_{6}$ molecules while impeding the diffusion of bulkier $\mathrm{C}_{3} \mathrm{H}_{8}$ molecules. In this context, $\mathrm{Ni}(\mathrm{AIP})(\mathrm{BPY})_{0.5}$ ranks as a new benchmark for efficient purification of $\mathrm{C}_{3} \mathrm{H}_{6}$ with a remarkably high $\mathrm{C}_{3} \mathrm{H}_{6}$ and $\mathrm{C}_{3} \mathrm{H}_{8}$ uptake ratio of 4.26 at $298 \mathrm{~K}$ and 1 bar. Computational results reveal the most uniform binding sites of $\mathrm{C}_{3} \mathrm{H}_{6}$ within these $1 \mathrm{D}$ narrow channels and also verify the obvious difference in diffusion rates of $\mathrm{C}_{3} \mathrm{H}_{6}$ among the three MOFs. The outstanding $\mathrm{C}_{3} \mathrm{H}_{6} / \mathrm{C}_{3} \mathrm{H}_{8}$ separation performance on $\mathrm{Ni}(\mathrm{AIP})(\mathrm{BPY})_{0.5}$ is confirmed by breakthrough experiments. In addition, $\mathrm{Ni}(\mathrm{AIP})(\mathrm{BPY})_{0.5}$ has good recycling capability, excellent water and moisture stabilities, which are favorable features for practical applications. This work provides an example that capitalizing on both thermodynamic and kinetic separation mechanisms is an effective strategy to achieve efficient $\mathrm{C}_{3} \mathrm{H}_{6} / \mathrm{C}_{3} \mathrm{H}_{8}$ separation.

\section{Corresponding Authors}

*E-mail: qbxia@scut.edu.cn (Q. X.) and w.y31@mail.scut.edu.cn (Y. W.)

\section{ACKNOWLEDGMENTS}

The authors gratefully acknowledge support from the National Natural Science Foundation of China (Nos. 21878101, 21808067, 21706031), China Postdoctoral Science Foundation (2018M640785), Guangdong Basic and Applied Basic Research Foundation (2019A1515011512, 2021A1515010172), Introduced Innovative R\&D Team Leadership of Dongguan City (2020607263005) 


\section{REFERENCES}

(1) Liang B, Zhang X, Xie Y, Lin RB, Krishna R, Cui H, Li Z, Shi Y, Wu H, Zhou W, Chen B. An ultramicroporous metal-organic framework for high sieving separation of propylene from propane. J. Am. Chem. Soc.2020; 142: 17795-17801.

(2) Wang X, Zhang P, Zhang Z, Yang L, Ding Q, Cui X, Wang J, Xing H. Efficient separation of propene and propane using anion-pillared metal-organic frameworks. Ind. Eng. Chem. Res. 2020; 59: 3531-3537.

(3) Chen Y, Wu H, Lv D, Yuan N, Xia Q, Li Z. A pillar-layer metal-organic framework for efficient adsorption separation of propylene over propane. Sep. Purif. Technol. 2018; 204: 75-80.

(4) Christopher CCE, Dutta A, Farooq S, Karimi IA. Process synthesis and optimization of propylene/propane separation using vapor recompression and self-heat recuperation. Ind. Eng. Chem. Res. 2017; 56: 14557-14564.

(5) Wang H, Liu Y, Li J. Designer metal-organic frameworks for size-exclusion-based hydrocarbon separations: progress and challenges.Adv. Mater. 2020; 32: e2002603.

(6) Wu H, Yuan Y, Chen Y, Xu F, Lv D, Wu Y, Li Z, Xia Q. Efficient adsorptive separation of propene over propane through a pillar-layer cobalt-based metal-organic framework. AIChE J. 2020; 66: e16858.

(7) Sholl DS, Lively RP. Seven chemical separations to change the world.Nature 2016; 532: 435-437.

(8) Wang Y, Huang NY, Zhang XW, He H, Huang RK, Ye ZM, Li Y, Zhou DD, Liao PQ, Chen XM, Zhang JP. Selective aerobic oxidation of a metal-organic framework boosts thermodynamic and kinetic propylene/propane selectivity. Angew. Chem. Int. Ed. 2019; 58: 7692-7696.

(9) Chen Y, Qiao Z, Lv D, Duan C, Sun X, Wu H, Shi R, Xia Q, Li Z. Efficient adsorptive separation of $\mathrm{C}_{3} \mathrm{H}_{6}$ over $\mathrm{C}_{3} \mathrm{H}_{8}$ on flexible and thermoresponsive CPL-1. Chem. Eng. J. 2017; 328: 360-367.

(10) Worrell E, Phylipsen D, Einstein D, Martin N. Energy use and energy intensity of the u.s. chemical industry.https://www.energystar.gov, 2000.

(11) Li K, Beaver M. Advanced nanostructured molecular sieves for energy efficient industrial separations.https://www.semanticscholar.org, 2012.

(12) Ding Q, Zhang Z, Yu C, Zhang P, Wang J, Cui X, He C, Deng S, Xing H. Exploiting equilibrium-kinetic synergetic effect for separation of ethylene and ethane in a microporous metal-organic framework. Sci. Adv. 2020; 6: eaaz4322.

(13) Cui WG, Hu TL, Bu XH. Metal-organic framework materials for the separation and purification of light hydrocarbons. Adv. Mater.2020; 32: e1806445.

(14) L J, Bhatt PM, Li J, Eddaoudi M, Liu Y. Recent progress on microfine design of metal-organic frameworks: structure regulation and gas sorption and separation. Adv. Mater. 2020; 32: e2002563.

(15) Yang L, Qian S, Wang X, Cui X, Chen B, Xing H. Energy-efficient separation alternatives: metal-organic frameworks and membranes for hydrocarbon separation. Chem. Soc. Rev. 2020; 49: 5359-5406.

(16) Yaghi OM, O'Keeffe M, Ockwig NW, Chae HK, Eddaoudi M, Kim J. Reticular synthesis and the design of new materials. Nature 2003; 423: 705-714.

(17) Zhu AX, Yang QY, Mukherjee S, Kumar A, Deng CH, Bezrukov AA, Shivanna M, Zaworotko MJ. Tuning the gate-opening pressure in a switching pcu coordination network, X-pcu-5-Zn, by pillar-ligand substitution. Angew. Chem. Int. Ed. 2019; 58: 18212-18217.

(18) Lin RB, Li L, Zhou HL, Wu H, He C, Li S, Krishna R, Li J, Zhou W, Chen B. Molecular sieving of ethylene from ethane using a rigid metal-organic framework. Nat. Mater. 2018; 17: 1128-1133. 
(19) Sen S, Hosono N, Zheng JJ, Kusaka S, Matsuda R, Sakaki S, Kitagawa S. Cooperative bond scission in a soft porous crystal enables discriminatory gate opening for ethylene over ethane. J. Am. Chem. Soc. 2017; 139: 18313-18321.

(20) Chen Y, Zhang X, Mian MR, Son FA, Zhang K, Cao R, Chen Z, Lee SJ, Idrees KB, Goetjen TA, Lyu J, Li P, Xia Q, Li Z, Hupp JT, Islamoglu T, Napolitano A, Peterson GW, Farha OK. Structural diversity of zirconium metal-organic frameworks and effect on adsorption of toxic chemicals.J. Am. Chem. Soc. 2020; 142: $21428-21438$.

(21) Chen Y, Idrees KB, Son FA, Wang X, Chen Z, Xia Q, Li Z, Zhang X, Farha OK. Tuning the structural flexibility for multi-responsive gas sorption in isonicotinate-based metal-organic frameworks. ACS Appl. Mater. Interfaces 2021; 13: 16820-16827.

(22) Bachman JE, Kapelewski MT, Reed DA, Gonzalez MI, Long JR. $\mathrm{M}_{2}$ (m-dobdc) $(\mathrm{M}=\mathrm{Mn}, \mathrm{Fe}, \mathrm{Co}, \mathrm{Ni})$ metal-organic frameworks as highly selective, high-capacity adsorbents for olefin/paraffin separations. $J$. Am. Chem. Soc. 2017; 139: 15363-15370.

(23) Cadiau A, Adil K, Bhatt PM, Belmabkhout Y, Eddaoudi M. A metal-organic framework-based splitter for separating propylene from propane. 2016; 353: 137-140.

(24) Wang H, Dong X, Colombo V, Wang Q, Liu Y, Liu W, Wang XL, Huang XY, Proserpio DM, Sironi A, Han Y, Li J. Tailor-made microporous metal-organic frameworks for the full separation of propane from propylene through selective size exclusion. Adv. Mater. 2018; 30: e1805088.

(25) Bao Z, Chang G, Xing H, Krishna R, Ren Q, Chen B. Potential of microporous metal-organic frameworks for separation of hydrocarbon mixtures. Energy Environ. Sci. 2016; 9: 3612-3641.

(26) Lee CY, Bae YS, Jeong NC, Farha OK, Sarjeant AA, Stern CL, Nickias P, Snurr RQ, Hupp JT, Nguyen ST. Kinetic separation of propene and propane in metal-organic frameworks: controlling diffusion rates in plate-shaped crystals via tuning of pore apertures and crystallite aspect ratios. J. Am. Chem. Soc. 2011; 133: 5228-5231.

(27) Li L, Lin RB, Wang X, Zhou W, Jia L, Li J, Chen B. Kinetic separation of propylene over propane in a microporous metal-organic framework. Chem. Eng. J. 2018; 354: 977-982.

(28) Xue DX, Cadiau A, Weselinski LJ, Jiang H, Bhatt PM, Shkurenko A, Wojtas L, Chen Z, Belmabkhout Y, Adil K, Eddaoudi M. Topology meets MOF chemistry for pore-aperture fine tuning: ftw-MOF platform for energy-efficient separations via adsorption kinetics or molecular sieving. Chem. Commun. 2018; 54: 6404-6407.

(29) Wang X, Krishna R, Li L, Wang B, He T, Zhang YZ, Li JR, Li J. Guest-dependent pressure induced gate-opening effect enables effective separation of propene and propane in a flexible MOF. Chem. Eng. J. 2018; 346: 489-496.

(30) Yoon JW, Seo YK, Hwang YK, Chang JS, Leclerc H, Wuttke S, Bazin P, Vimont A, Daturi M, Bloch E, Llewellyn PL, Serre C, Horcajada P, Greneche JM, Rodrigues AE, Ferey G. Controlled reducibility of a metal-organic framework with coordinatively unsaturated sites for preferential gas sorption. Angew. Chem. Int. Ed. 2010; 49: 5949-5952.

(31) Geier SJ, Mason JA, Bloch ED, Queen WL, Hudson MR, Brown CM, Long JR. Selective adsorption of ethylene over ethane and propylene over propane in the metaL-organic frameworks $\mathrm{M}_{2}(\mathrm{dobdc})(\mathrm{M}=\mathrm{Mg}$, Mn, Fe, Co, Ni, Zn). Chem. Sci. 2013; 4: 2054-2061.

(32) Burtch NC, Jasuja H, Walton KS. Water stability and adsorption in metal-organic frameworks. Chem. Rev. 2014; 114: 10575-10612.

(33) Ding Q, Zhang Z, Yu C, Zhang P, Wang J, Kong L, Cui X, He CH, Deng S, Xing H. Separation of propylene and propane with a microporous metal-organic framework via equilibrium-kinetic synergetic 
effect.AIChE J. 2020; 67: e17094.

(34) Hu Y, Zhang W, Zhang X, Wang Z, Li Y, Bai J. Two corrugated 2D bilayer $\left(6^{3}\right)\left(6^{5} 8\right)$ topological coordination polymers: synthesis, structure, and water-induced reversible transformation. Inorg. Chem. Commun. 2009; 12: 166-168.

(35) Xu DX, Wang CC, Wang P, Li J, Guo XX, Gao SJ. Two novel 2D coordination polymers constructed from 5-aminoisophthalic acid and 4,4'-bipyridyl ligands: syntheses, crystal structure, and photocatalytic performance. J. Mol. Struct. 2017; 1135: 129-137.

(36) Li J, Xu F, Si X, Sun L, Jiao Q, Jiao C, Gu Z, Xin H. Heat capacities and thermodynamic properties of $\left[\mathrm{Co}(\mathrm{AIP})(\mathrm{BPY})_{0.5} \cdot \mathrm{H}_{2} \mathrm{O}\right]_{\mathrm{n}} \cdot 2 \mathrm{nH}_{2} \mathrm{O}$. Thermochim. Acta $2013 ; 566$ : 15-18.

(37) Senthilkumar S, Goswami R, Obasi NL, Neogi S. Construction of pillar-layer metal-organic frameworks for $\mathrm{CO}_{2}$ adsorption under humid climate: high selectivity and sensitive detection of picric acid in water. $A C S$ Sustainable Chem. Eng. 2017; 5: 11307-11315.

(38) Kim AR, Yoon TU, Kim EJ, Yoon JW, Kim SY, Yoon JW, Hwang YK, Chang JS, Bae YS. Facile loading of $\mathrm{Cu}(\mathrm{I})$ in MIL-100(Fe) through redox-active $\mathrm{Fe}(\mathrm{II})$ sites and remarkable propylene/propane separation performance.Chem. Eng. J. 2018; 331: 777-784.

(39) Plaza MG, Ferreira AFP, Santos JC, Ribeiro AM, Müller U, Trukhan N, Loureiro JM, Rodrigues AE. Propane/propylene separation by adsorption using shaped copper trimesate MOF. Microporous Mesoporous Mater.2012; 157: 101-111.

(40) Bao Z, Alnemrat S, Yu L, Vasiliev I, Ren Q, Lu X, Deng S. Adsorption of ethane, ethylene, propane, and propylene on a magnesium-based metal-organic framework. Langmuir 2011; 27: 13554-13562.

(41) Walton KS, Sholl DS. Predicting multicomponent adsorption: 50 years of the ideal adsorbed solution theory. AIChE J. 2015; 61: 2757-2762.

(42) Li B, Zhang Y, Krishna R, Yao K, Han Y, Wu Z, Ma D, Shi Z, Pham T, Space B, Liu J, Thallapally PK, Liu J, Chrzanowski M, Ma S. Introduction of $\pi$-complexation into porous aromatic framework for highly selective adsorption of ethylene over ethane. J. Am. Chem. Soc. 2014; 136: 8654-8660.

(43) Chen Y, Wu H, Yuan Y, Lv D, Qiao Z, An D, Wu X, Liang H, Li Z, Xia Q. Highly rapid mechanochemical synthesis of a pillar-layer metal-organic framework for efficient $\mathrm{CH}_{4} / \mathrm{N}_{2}$ separation. Chem. Eng. J.2020; 385: 123836. 